\title{
MODAL SOSIAL DALAM PENGEMBANGAN URBAN FARMING DI KAMPUNG HIDROPONIK KELURAHAN PENGADEGAN, JAKARTA SELATAN
}

\author{
Arief Subangkit, Dini Fajar Yanti, Lidya Maria Kusnadi, \\ dan Mochammad Ikbal Sonuari \\ Universitas Indonesia \\ Email: ariefsubangkit@ui.ac.id
}

\begin{abstract}
The purpose of this research is to describe the form of social capital in the development of urban farming in the hydroponic village of Pangadegan, South Jakarta, DKI Jakarta. Data collection is done through interviews, documentation and observation. Data is processed and analyzed through a three-stage data encoding technique: open encryption, axial encryption and selective encryption. Arguments are formulated through analysis using Putnam's social capital theory which focuses on networks, norms, and beliefs. The result is that social capital in developing urban farming in Pengadegan Village can be described in 3 ways, namely ties of trust, social institutions, and social networks. Relating to the bond of trust can be seen from the community including Gapoktan and the Village Government have the same passion and commitment to greening the environment and building community cohesiveness. Besides that, from social institutions, it can be seen that Gapoktan has its own written rules, both Gapoktan Gang B and Gang C. The written rules contain the duties and functions of each member. Social networks can be seen by showing that there are two Gapoktan who have different principles, Gapoktan in Gang C chooses to independently develop Hidroponik village, Gapoktan in Gang B prefers to develop the widest network both for the government and the private sector.
\end{abstract}

Keywords: Social Capital; Urban Farming, Hidroponik Village.

Abstrak. Tujuan dari penelitian ini adalah untuk menggambarkan bentuk modal sosial dalam pengembangan urban farming di kampung hidroponik Kelurahan Pangadegan Kota Jakarta Selatan DKI Jakarta. Pengumpulan data dilakukan melalui teknik wawancara, dokumentasi dan observasi. Data diolah dan dianalisis melalui teknik tiga tahap penyandian data: penyandian terbuka, penyandian aksial dan penyandian selektif. Argumen dirumuskan melalui analisis dengan menggunakan teori modal sosial dari Putnam yang memfokuskan pada jaringan, norma, dan kepercayaan. Dari hasil analisis peneliti ditemukan bahwa modal sosial dalam pengembangan urban farming di Kelurahan Pengadegan dapat digambarkan dalam 3 hal yaitu ikatan kepercayaan, pranata sosial, dan jaringan sosial. Berkaitan dengan ikatan kepercayaan dapat dilihat dari masyarakat termasuk Gapoktan dan Pemerintah Kelurahan memiliki semangat dan komitmen yang sama yakni untuk menghijaukan lingkungan dan membangun kohesifitas masyarakat. Selain itu dari pranata sosial dapat dilihat Gapoktan memiliki aturan tertulis masingmasing, baik Gapoktan Gang B maupun Gang C. Aturan tertulis tersebut berisi tugas dan fungsi masing-masing anggota. Jaringan sosial dapat dilihat dengan menunjukkan bahwa terdapat dua Gapoktan yang memiliki prinsip yang berbeda, Gapoktan di Gang C memilih untuk secara mandiri mengembangkan Kampung Hidroponik, Gapoktan di Gang B lebih memilih untuk mengembangkan jaringan seluas-luasnya baik kepada pemerintah maupun swasta.

Kata Kunci: Modal Sosial; Urban Farming, Kampung Hidroponik 


\section{Pendahuluan}

Pembangunan yang berfokus pada keberlanjutan lingkungan menjadi agenda utama Sustainable Development Goal's (SDG). Namun sangat disayangkan, pembangunan yang marak terjadi di negara-negara berkembang, khususnya yang dialami negeri ini belum sepenuhnya menggunakan pembangunan yang berwawasan lingkungan. Kota sebagai salah satu pusat peradaban manusia, memungkinkan membawa kemajuan ekonomi, mempromosikan inovasi dan kohesi sosial, dan meningkatkan akses bagi jutaan orang terhadap layanan kesehatan, pendidikan, air minum dan listrik.

Pembangunan berkelanjutan tidak dapat dicapai tanpa mengubah cara kita membangun dan mengelola ruang perkotaan kita secara signifikan (UNDP, 2016). Data Badan Pusat Statistik (BPS, 2018) menunjukkan bahwa pada tahun 2018 hampir separuh penduduk Indonesia tinggal di kota, bahkan diproyeksikan akan naik menjadi 67 persen pada 2035. Per Maret 2018 disebutkan sejumlah 7,02 persen penduduk perkotaan berada di bawah garis kemiskinan. Di kotakota dua masalah yang paling mendesak yang dihadapi dunia saat ini juga datang bersamaan adalah kemiskinan dan degradasi lingkungan.

Perencanaan kota memiliki peran mendasar untuk mendorong kota layak huni dan berkelanjutan, termasuk melalui pengoptimalan lahan di dalam kota. Namun banyak kota di Indonesia mengabaikan atau tidak mengintegrasikan dengan baik kegiatan pertanian perkotaan (urban farming) ke dalam proses perencanaan kebijakan. Pertumbuhan infrastruktur dan perumahan yang begitu pesat di perkotaan mengakibatkan lahan hijau semakin berkurang. Asupan pangan dari daerah rural memang bisa menjadi pilihan, namun dengan harga yang cenderung tinggi, salah satunya dikarenakan jarak. Untuk beberapa komunitas kota dengan penghasilan rendah, hal ini menjadi kerentanan terhadap ketahanan pangan.

Midgley (1997) menyebutkan bahwa kesejahteraan sosial merupakan suatu kondisi kehidupan manusia yang tercipta ketika berbagai permasalahan sosial dapat dikelola dengan baik, kebutuhan manusia dapat terpenuhi dan kesempatan sosial dapat dimaksimalkan. Kesejahteraan Sosial merupakan bidang keilmuan yang eklektik dan memiliki kekhasan pada "keberfungsian sosial" individu dan masyarakat. Isu degradasi lingkungan yang berdampak pada krisis pangan telah menjadi masalah sosial global dan perhatian dunia, oleh karenanya perlu strategi pembangunan sosial terintegrasi yang berwawasan lingkungan. 
- Arief Subangkit, Dini Fajar Yanti, Lidya Maria Kusnadi, dan Mochammad Ikbal Sonuari

UNDP (1996) memperkirakan 800 Juta orang di seluruh dunia telah terlibat dalam pertanian perkotaan (urban farming). Urban farming merupakan konsep memindahkan pertanian konvensional ke pertanian perkotaan, yang berbeda yakni pada pelaku dan media tanamnya. Pertanian konvensional lebih berorientasi pada hasil produksi, sedangkan urban farming lebih pada karakter pelakunya yakni masyarakat urban. Urban farming telah menjadi gaya hidup karena semakin tinggi kesadaran masyarakat urban untuk menjalani gaya hidup sehat.

Sejak 2016 beberapa tahun lalu, konsep Urban Farming mulai marak di Indonesia. Di Jakarta sendiri salah satu daerah yang gencar menjalankan praktik Urban Farming adalah Rukun Warga (RW) 001 Kampung Hidroponik Pengadegan. Terdorong karena melihat kondisi masyarakat yang kekurangan bahan pangan berkualitas dan tidak terpenuhinya hak-hak dasar sebagai manusia seperti tidak terpenuhinya gizi keluarga. Mursyid, lurah setempat yang merupakan lulusan program Magister Manajemen Agribisnis Institut Pertanian Bogor (IPB) memprakarsai program Kampung Hidroponik Pengadegan. Saat ini di Kampung Pengadegan, sudah ada empat RW yang mengaplikasikan Kampung Hidroponik, yakni RW01, RW03, RW07 dan RW08. Dan akan bertambah lagi RW yang mengikuti. Pengelolaan kebun hidroponik ini seluruhnya dilakukan secara mandiri oleh warga setempat, dengan pendanaan yang berasal dari penjualan sayuran atau dana CSR.

Urban farming yang awalnya dimulai untuk meningkatkan kualitas pangan kemudian berkembang memberikan efek domino pada komunitas khususnya kewirausahaan dan gerakan komunitas ke arah positif, sehingga program ini memberikan dampak ekonomi dan sosial. Hal lain yang tampak dalam konsep urban farming di masyarakat adalah munculnya karakterisitik modal sosial dalam komunitas. Modal sosial, dianggap sebagai jembatan antara konsep sosial dan ekonomi. Menurut Liu (2014) konsep modal sosial telah menjadi pertimbangan dalam berbagai bidang penelitian di beberapa dekade terakhir.

Berbicara mengenai modal sosial, konsep ini pertama kali dikemukakan oleh Pierre Bourdieu. Menurut Bourdieu (1992) modal sosial dapat didefinisilan sebagai jumlah sumber daya, baik yang bersifat nyata maupun tersirat. Sumber ini berkembang pada individu maupun kelompok karena adanya jaringan yang telah diinstitusikan berdasarkan pengetahuan maupun adanya hubungan timbal balik. Pemahaman lain mengenai modal sosial dapat dilihat juga 
menurut sudut pandang James L. Coleman (1988) yang mengungkapkan bahwa terdapat 3 jenis kapital dalam seorang individu : kapital fisik, kapital manusia, dan kapital sosial. Modal (kapital) sosial menurut Coleman berkaitan dengan beberapa aspek dari struktur sosial dan penurunan fungsi atau hilangnya salah satu kapital akan menyebabkan penurunan produktifitas seseorang. Tokoh lain yang juga mendifinisikan mengenai modal sosial adalah Putnam (1996). Putnam menyatakan bahwa modal sosial adalah unsur kehidupan sosial yang berbentuk jaringan, norma, dan kepercayaan yang memungkinkan partisipan untuk bertindak bersama dalam mewujudkan tujuan bersama.

Dengan kata lain, modal sosial mengasumsikan bahwa sumber daya yang ada dalam suatu hubungan sosial dapat mendukung terwujudnya tujuan-tujuan yang diharapkan dalam suatu komunitas atau jaringan tertentu. Dalam hal ini, berkaitan dengan keberhasilan atau terwujudnya kesejahteraan sosial.

Kajian difokuskan pada elemen utama dalam modal sosial menurut Putnam (1996) yaitu jaringan, norma, dan kepercayaan. Jaringan atau ikatan (ties) sosial meliputi aktor (individu) sebagai pelaku yang memiliki hubungan sosial baik dengan individu lain maupun kelompoknya, aktor atau kelompok dalam jaringan sosial ini saling terikat untuk mencapai tujuan tertentu (Castiglione, dkk. 2007). Norma sosial dapat didefinisikan sebagai sekumpulan aturan yang mengikat individu dalam komunitas tertentu. Norma memiliki peran yang besar dalam mengontrol bentuk perilaku yang tumbuh dalam suatu komunitas, karena norma biasanya mengandung sanksi. Meski begitu, norma muncul dari pertukaran yang saling menguntungkan (Fukuyama, 1999), artinya, kedua belah pihak harus diuntungkan.

Jika hanya terjadi satu pihak, pertukaran sosial tidak terjadi. Karenanya, norma terjadi dari lebih dari satu pertukaran (Lawang, 2005). Sementara kepercayaan menurut Eric . M. Uslaner dalam Handbook of Social Capital, dibedakan menjadi dua, yaitu kepercayaan moralistik dan kepercayaan strategis. Kepercayaan moralistik berkenaan dengan bagaimana seseorang harus bersikap, sementara kepercayaan strategis mengacu pada harapan tentang bagaimana seseorang akan berperilaku (Castiglione, 2007).

\section{Metode}

Pendekatan yang digunakan dalam penelitian ini adalah pendekatan penelitian kualitatif. Pemilihan penggunaan pendekatan penelitian ini didasari 
pemikiran Bogdan et. all bahwa metode kualitatif sebagai prosedur penelitian yang menghasilkan data deskriptif berupa kata-kata tertulis atau lisan dari orang-orang dan perilaku yang dapat diamati.

Jenis penelitian yang akan digunakan dalam penelitian ini adalah fenomenologi. Fenomenologi merupakan upaya pemberangkatan dari metode ilmiah yang berasumsi bahwa eksistensi suatu realitas tidak orang ketahui dalam pengalaman biasa. Fenomenologi membuat pengalaman yang dihayati secara aktual sebagai data dasar suatu realitas.

\section{Analisa Data}

Dalam penelitian ini, teknik analisis data dimulai dengan mengumpulkan data mentah dari lapangan, melakukan transkrip data, membuat koding, membuat kategorisasi data, menginterpretasi data, melakukan memberchecking, melakukan trianggulasi, melakukan peer examination dan membuat kesimpulan akhir. Langkah-langkah ini peneliti susun dengan mengkolaborasikan antara teori Nueman dengan Laura Krefting.

\section{Hasil dan Diskusi}

Hal ini tergambarkan pada Kampung Hidroponik di Pengadegan yang membuat urban farming. Permulaan munculnya kegiatan ini, hanya dilakukan beberapa warga yang akan menjadi petani kota. Mereka dilatih tentang bertani menggunakan media non tanah menggunakan teknik Hidroponik. Lurah Pengadegan kemudian melakukan pembahasan dengan warga. Tujuan dari urban farming atau Pertanian di dalam kota mempengaruhi aspek ekonomi, kesehatan, sosial dan lingkungan kota. Dengan demikian akan ada manfaat meningkatnya kesejahteraan, keadilan, kebersamaan, kenyamanan, kualitas kehidupan dan kelestarian lingkungan hidup.

\section{Ikatan Kepercayaan}

Temuan penelitian tentang ikatan kepercayaan masyarakat menunjukan bahwa masyarakat termasuk Gapoktan dan pemerintah kelurahan memiliki semangat dan komitmen yang sama yakni untuk menghijaukan lingkungan dan membangun kohesifitas masyarakat. Transformasi citra negatif yakni kumuh dan miskin menjadi kampung hijau dan asri merupakan cita-cita bersama masyarakat. Namun tidak dapat dipungkiri seiring berjalannya waktu, terdapat konflik internal yang terjadi terkait perbedaan prinsip tentang pengelolaan 
Hidroponik yang menjadikan pengelolaan Kampung Hidroponik terpecah menjadi dua yakni oleh Gapoktan di Gang B dan C.

\section{Pranata Sosial}

Gapoktan memiliki aturan tertulis masing-masing, baik Gapoktan Gang B maupun Gang C. Aturan tertulis tersebut berisi tugas dan fungsi masing-masing anggota, termasuk aturan terkait manajemen Hidroponik. Aturan tertulis inilah yang mengatur langkah manajemen Hidroponik masing-masing kelompok. Namun disisi lain, masyarakat memiliki aturan tidak tertulis berupa nilai-nilai yang ditanamkan untuk ikut serta menjaga dan merawat tanaman Hidroponik di lingkungannya.

\section{Jaringan Sosial}

Temuan di lapangan menunjukkan bahwa terdapat dua Gapoktan yang memiliki prinsip yang berbeda dalam pengelolaan Kampung Hidroponik. Gapoktan di Gang C memilih untuk secara mandiri mengembangkan Kampung Hidroponik tanpa membangun jaringan kerjasama dengan berbagai pihak. Gapoktan Gang C tetap menerima kerjasama dan jejaring sosial dengan berbagai pihak namun tidak berusaha untuk mengembangkannya. Gapoktan Gang C juga menerima bantuan berupa dana dan bahan material bangunan, namun tidak dikembangkan lebih lanjut. Di sisi lain, Gapoktan di Gang B lebih memilih untuk mengembangkan jaringan seluas-luasnya baik kepada pemerintah maupun swasta.

\section{Kesimpulan}

Dari hasil kajian yang difokuskan pada elemen utama dalam modal sosial menurut Putnam (1996) yaitu jaringan, pranata sosial (norma), dan kepercayaan, terlihat bahwa pada Kampung Hidroponik Kelurahan Pengadegan terdapat kepercayaan dalam mengembangkan kampung hidroponik Konflik internal masyarakat terkait pengelolaan Hidroponik dapat terselesaikan secara kekeluargaan. Semangat dan komitmen yang sama untuk menghijaukan lingkungan dan membangun kohesifitas masyarakat. Kepengurusan yang transparan, jujur dan terbuka merupakan modal utama kepercayaan antara warga dan pengurus Gapoktan.

Edukasi dan pemberian contoh merupakan media membangun 
- Arief Subangkit, Dini Fajar Yanti, Lidya Maria Kusnadi, dan Mochammad Ikbal Sonuari

kepercayaan dan partisipasi masyarakat. Penetapan aturan yang dilegitimasi antara masyarakat dan pemerintah Kelurahan menjadi media perekat kepercayaan masyarakat terhadap pengelolaan Kampung Hidroponik. Hal tersebut menjadi sebuah elemen kepercayaan dalam mengembangkan urban farming di kampung hidroponik.

\section{Daftar Pustaka}

Badan Pusat Statistik. Publikasi Statistik Modal Sosial 2014-2016.

Coleman, S. J. (2011). Dasar-Dasar Teori Sosial: Foundation of Social Theory.

Edisi Revisi. Diterjemahkan oleh Imam Muttaqien, Derta Sri Widowatie, dan Siwi Purwandari. Bandung: Penerbit Nusa Media.

Fukuyama, F. (1995). Trust : The Social Virtues and The Creation of Prosperity.

New York: Free Press.

Hasbiansyah, O. (2008). Pendekatan Fenomenologi: Pengantar Praktik Penelitian

dalam Ilmu Sosial dan Komunikasi. MediaTor (Jurnal Komunikasi), 9(1), 163180.

Hasbullah, J. (2006). Sosial Kapital: Menuju Keunggulan Budaya Manusia Indonesia .Jakarta: MR United Press.

Koentjaraningrat. (2005). Pengantar Antropologi II. Jakarta: Rineka Cipta.

Putnam R. (1993). Making Democracy Work: Civic Tradition in Modern Italy.

Princeton: Princeton University Press.

Sage, C. (2002) Food Security and Environment. In Page \& Redclift, ed. Human

Security and The Environment: International Comparisons. Cheltenham:

Edward Elgar, pp 128-153.

Soekanto, Soerjono. (2003). Sosiologi Suatu Pengantar . Cetakan Ke-35. Jakarta: PT Raja Grafindo Persada. 